\title{
OPTIMALISASI DIGITAL MARKETING DI MASA PANDEMI DI KELURAHAN PANEMBAHAN, KRATON, DIY
}

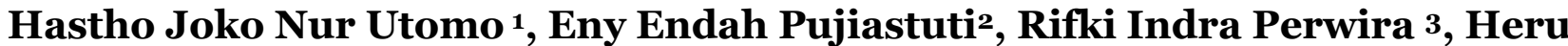 C. Rustamadji4}

1Department of Business Administration, Univeritas Pembangunan Nasional "Veteran” Yogyakarta, Indonesia

2Department of Business Administration, Univeritas Pembangunan Nasional "Veteran” Yogyakarta, Indonesia

3Department of Informatika, Univeritas Pembangunan Nasional “Veteran” Yogyakarta, Indonesia

1 hastho.joko@upnyk.ac.id; 2 eny.endahp@upnyk.ac.id 3 rifki@upnyk.ac.id

\begin{abstract}
Since the covid pandemic entered the DIY area, residents of the community of $R W$ 13, Panembahan Village have been affected. Public opinion decreased. The community service team from UPN veteran Yogyakarta is trying to help overcome this with community empowerment programs through digital business / digital marketing. Continuously and slowly the condition of the people's income can increase again. Promotion through social media is optimized through whatssapp groups, Instagram and market places.
\end{abstract}

Keywords: community empowerment, digital business, digital marketing

\begin{abstract}
Abstrak
Sejak pandemic covid masuk ke wilayah DIY, warga masyarakat RW 13 Kelurahan Panembahan terkena dampaknya. Pendapat warga masyarakat menurun. Tim pengabdian masyarakat dari UPN veteran Yogyakarta berusaha membantu mengatasi hal ini dengan program pemberdayaan masyarakat melalui digital bisnis/ digital marketing. Secara berkelanjutan dan perlahan kondisi penghasilan warga masyarakat bisa meningkat kembali. Promosi melalui medsos dioptimalkan melalui whatssapp grup, Instagram dan market place.
\end{abstract}

Kata Kunci: pemberdayaan masyarakat, digital bisnis, digital marketing.

\section{PENDAHULUAN}

Kelurahan Panembahan merupakan salah satu kelurahan yang ada di kecamatan Kraton, Yogyakarta, Daerah

Istimewa Yogyakarta 
Berdasarkan data monografi desa, jumlah penduduk Kelurahan Panembahan tahun 2020 sebanyak 4.968 jiwa, meliputi; laki-laki 2.222 jiwa dan perempuan 2.746 jiwa dan merupakan penduduk terbanyak dibandingkan kelurahan lain yang berada di Kecamatan Kraton. Kelurahan ini memiliki jumlah RW/RT terbanyak yaitu 18 RW dan 78 RT.

Mata pencaharian warga masyarakat di kelurahan Panembahan diantaranya: percetakan, tukang cukur, tukang jahit, salon, reparasi sepeda \& sepeda motor , bengkel mobil, service elektronik. Sebagian warganya juga berprofesi sebagai pedagang kaki lima dan jasa tour guide.

Secara historis lembaga RW 13 Kelurahan Panembahan, muncul ketika ditetapkannya perubahan dari Rukun Kampung (RK) menjadi Rukun Warga (RW) pada akhir tahun 1980-an, yaitu RK Panembahan terdiri dari 4 RW, yaitu RW 11, 12, 13 dan 14.

Sejak bulan Maret 2019 aneka usaha jasa dan perdagangan yang ada di kelurahan Panembahan terpuruk karena adanya virus covid 19, masyarakat diwajibkan work from home, tidak bisa leluasa keluar rumah untuk membeli kebutuhan sehari-hari seperti sembako, makanan yang sudah matang dan sebagainya, penjualan industri menurun sehingga pendapatan masyarakat menurun.

Wabah covid 19 mempengaruhi seluruh kehidupan masyarakat terutama masyarakat yang memiliki bisnis kuliner dan bisnis lain. Dampaknya berupa menurunnya penjualan bisnis masyarakat sehingga mempengaruhi pendapatan masyarakat. Hal ini dapat berakibat buruk pada ekonomi masyarakat RW 13 kelurahan Panembahan. Pendapatan dan perekonomian pedagang kaki lima dan pemberi jasa tour guide mengalami penurunan karena adanya kebijakan dari Keraton Yogyakarta yang memindahkan kawasan parkir di sekitar kawasan wisata Keraton ke kawasan parkir Ngabean dan Abu Bakar Ali. Selain itu masih terdapat penduduk yang memasuki usia produtif tapi belum menggunakan kemampuan secara maksimal.

Berdasarkan

Rencana

Pembangunan Jangka Menengah (RPJM) Kelurahan Panembahan tahun 2015-2020 diketahui bahwa fokus kebijakan pembangunan Kelurahan Panembahan diutamakan pada pembangunan ekonomi karena banyaknya pengangguran dan untuk meningkatkan pendapatan masyarakat. Hasil diskusi antara perguruan tinggi pengusul, Ketua RW 13 disepakati beberapa program dan kegiatan sebagai 
solusi yang diprioritaskan untuk ditangani selama satu tahun.

\section{METODE DAN PELAKSANAAN}

Bagian ini berisi metode pengabdian dan pelaksanaan kegiatan.

\section{Metode}

Beberapa metode kegiatan antara lain: (1) training/pelatihan terkait barang maupun jasa, difusi ipteks, substitusi ipteks (ipteks terbarukan), atau simulasi ipteks; (2) penyadaran/peningkatan pemahaman terhadap suatu masalah; (3) konsultasi/pendampingan/mediasi.

\section{Pelaksanaan Kegiatan}

Pendekatan yang diterapkan dalam kegiatan ini berupa inkubator bisnis, yang pada intinya adalah memberikan pelatihan untuk membuka wawasan, menyusun rencana serta mengimplementasikan program serta melakukan pendampingan.

\section{HASIL DAN PEMBAHASAN}

\section{Strategi Bisnis Produk Kuliner di Masa Pandemi}

Pandemi covid telah membawa dampak negatif bagi berbagai macam usaha bisnis di masyarakat DIY, termasuk juga di RW 13 Kelurahan Panembahan Kecamatan Kraton Kota Yogyakarta. Berkurangnya jumlah pembeli sejak bulan Maret hingga Nopember 2020 ini telah mengakibatkan penurunan pendapatan para pelaku bisnis. Kondisi ini tidak bisa dibiarkan terjadi terus-menerus.

Sejumlah dosen Universitas Pembangunan Nasional UPN Veteran Yogyakarta (UPNVY) berupaya mengimplementasikan pengetahuannya untuk membantu mengatasi permasalahan tersebut. Dukungan yang diberikan dalam rangkaian pengabdian masyarakat itu diwujudkan lewat focus group discussion (FGD) bertema Strategi Bisnis Kuliner di Era Pandemi dan Era New Normal yang digelar pada Sabtu sore (8/8/2020) jam 16.00-18.oo. Beberapa dosen UPNVY yang terlibat dalam kegiatan itu diantaranya Hastho Joko Nur Utomo, Eny Endah Pujiastuti, serta Rifki Indra Perwira. Sedikitnya 15 orang owner bisnis hadir dalam kegiatan tersebut.

Eny Endah Pujiastuti menjelaskan bahwa kegiatan pemasaran secara on line merupakan solusi di masa sekarang ini. Produk yang berupa makanan bisa dipromosikan melalui lewat go food atau melalui grup whatsapp. Bisa juga dipromosikan melalui market place sebagaimana produk yang dipasarkan melalui buka lapak.com.

Rifki Indra Perwira membenarkan bahwa di era teknologi informasi saat ini pemasaran produk kuliner sebaiknya diarahkan pada pemasaran digital, 
sehingga berbagai produk yang dijual bisa diketahui oleh masyarakat luas. Hanya saja, risikonya pelaku bisnis kuliner tidak mudah untuk memperkirakan stock produk yang harus disediakan, kadang stock berlebih dan kadang kurang. Dengan itu dia berharap pembeli dari luar daerah merasa ingin tahu dan kemudian datang untuk berkunjung. "Kami memberikan beberapa tips dan teknik promosi bisnis kuliner melalui website dan instagram kepada warga dan pengelola bisnis kuliner. Prinsipnya adalah teknik mana yang paling mudah diterapkan oleh warga, maka itulah teknik yang dipilih “, ujarnya.

\section{Promosi Produk melalui Story marketing di face book dan berbagai grup whatshapp}

Strategi pemasaran yang menggunakan cerita dalam menjelaskan produk yang ditawarkan dapat mendorong minat konsumen untuk memahami informasi yang lebih rinci. Oleh karena itu, Story marketing dapat dikatakan sebagai cara terbaik untuk menyentuh hati konsumen. Pemasaran cerita adalah faktor keberhasilan paling berharga dalam penjualan dan dapat mengubah nilai penjual (seller value) menjadi nilai pembeli (buyer value) (Min Li, 2014). Jika story marketing berhasil maka akan menimbulkan kepercayaan pada konsumen. Saat konsumen percaya pada kualitas produk dan harga menjadi ambang dasar, nilai tambah dari suatu produk akan menjadi kunci suksesnya.

Mendongeng adalah metode untuk berbagi wawasan (Stickdorn dan Schneider (2010). Cerita bisa dikomunikasikan dan ditafsirkan dengan berbagai cara. Mendongeng telah menjadi teknik untuk meningkatkan emosi konsumen. Sebuah cerita dapat menjadi aset nilai tambah, seperti yang dijelaskan dalam Aaker (1991) definisi ekuitas merek sebagai "seperangkat aset dan kewajiban merek yang terkait dengan merek, nama dan simbolnya, yang menambah atau mengurangi nilai yang diberikan oleh produk atau layanan kepada perusahaan dan / atau pelanggan perusahaan itu.

Bercerita (Storytelling) terdiri dari instrumen komunikasi (yaitu cerita, media sosial, elemen visual) yang memiliki tempat penting dalam strategi pemasaran konten, adalah salah satu cara yang paling kuat, cepat, dan efektif untuk memberikan kehidupan baru ke dalam merek dan mendorong perubahan pasar (Fog, Budtz dan Yakaboylu, 2005). Cerita dapat diceritakan dengan menggunakan kata-kata, gambar, atau 
campuran keduanya (Facebook IQ,2015). Cara penyampaian cerita bergantung pada apa yang dicoba dikomunikasikan oleh pendongeng kepada audiens. Konsumen mencari pengalaman yang menarik emosi dan impian mereka, dan cerita membantu menciptakan pengalaman seperti itu (Fog et al, 2005, Silverstein and Fiske, 2003).

Storytelling dapat dipergunakan dalam strategi pemasaran usaha kecil dan industry rumah tangga karena mendongeng dapat berbagi norma dan nilai, mengembangkan kepercayaan dan komitmen, berbagi dan menyimpan pengetahuan tacit (tacit knowledge), memfasilitasi unlearning, menghasilkan hubungan emosional, merangsang imajinasi, dan memulai perubahan (Sole dan Wilson, 1999).

\section{Mendongeng (Bercerita/ Story} telling) dapat digunakan usaha kecil dan usaha rumah tangga untuk menginformasikan pelanggan yang ada dan pelanggan potensial tentang keberadaan usaha tersebut (Jensen, 1999). Penggunaan dongeng merupakan faktor kunci yang tepat untuk memperkenalkan produk yang diproduksi oleh usaha kecil dan usaha tumah tangga kepada konsumen, dengan cara yang menyenangkan dan mendidik.

Elemen yang mempengaruhi storytelling seperti: a. mengidentifikasi sudut pandang dan kebutuhan orang lain,

b. memahami bagaimana orang lain ingin bekerja dengan Anda;

c. memahami apa yang mendorong orang, misalnya apakah mereka suka mendengar tentang kerja sama atau konflik, apakah mereka lebih suka yang serius atau lucu pendekatan, dan bagaimana mereka dipengaruhi - apakah mereka 'tangguh pejuang ',' pembantu ramah 'atau' pemikir logis '.

Sebuah cerita adalah sebuah narasi (idealnya dengan plot), benar atau sesuai, dirancang untuk menarik, menghibur atau memberi petunjuk kepada pendengar atau pembaca. Cerita membangkitkan emosi dan minat. Sebuah cerita bisa menciptakan aspirasi.Cerita membujuk. Cerita menghibur. Cerita membuat orang-orang berpihak pada Anda. Kisah-kisah terbaik itu sederhana, tetapi diceritakan dengan baik. Bercerita yang baik menuntut pemahaman tentang sudut pandang penonton, bahkan mungkin penonton yang menjadi tujuan penyampaian cerita Anda. Sebuah cerita yang bagus menangkap dan menarik perhatian, membangkitkan minat,mendorong keterlibatan, mengembangkan pemahaman dan menstimulasi emosi orang-orang yang dipersiapkan (Stone, Machtynger and Machtynger, 2015) 
Cerita dalam kegiatan pemasaran usaha kecil atau usaha rumah tangga bias dilakukan oleh pengelola usaha atau konsumen itu sendiri. Kakroo (2015) mengemukakan tiga poin utama untuk storytelling, yaitu plot, karakter, dan estetika, yaitu:

a. Plot: berisi awal, interval, dan akhir. Sebuah cerita tidak akan terbentuk tanpa plot, dan plot menentukan tindakan dalam sebuah cerita.

b. Karakter: Tindakan tidak akan dihasilkan dalam plot tanpa karakter. Merek yang pandai bercerita merek menjadi karakter dalam konsumen kehidupan; Selain itu, merek memungkinkan konsumen menjadi lebih banyak persuasif dari karakter dalam hidup.

c. Estetika: Kostum, dekorasi, gaya jitu, dan keterampilan retoris dalam naratif akan membuat sebuah cerita lebih menarik.

Teknologi yang berkembang seperti adanya internet dapat dipergunakan untuk media mendongeng. Digital Storytelling adalah sarana untuk berbagi informasi yang dapat diakses oleh semua, sangat interaktif, meliputi visual, tulisan, percakapan, etnik (tribal), branding, broadcasting dan cerita organisasi. Pengusaha dalam mempergunakan Digital Storytelling harus memperhatikan segmentasi konsumen yang akan dituju, karena beda generasi akan berbeda dalam mempergunakan media social nya. Generasi adalah kohort dengan seperangkat ciri kepribadian dan pola perilaku homogen, yang membedakan dengan generasi sebelumnya dan generasi selanjutnya (Domingues, 2002)..

Digital Storytelling dapat menggunakan media social. Media sosial telah berkembang menjadi saluran penting untuk pemasaran (Kaplan \& Haenlein, 2010) sehingga media sosial bisa meningkatkan peran konsumen dalam penciptaan merek dan komunikasi bersama (Lund, Cohen \& Scarles, 2018). Sumber media sosial bagus untuk konten (YouTube, blog, studi kasus, pembicaraan TED, dll). Cerita online memiliki potensi untuk memengaruhi sejumlah besar pengunjung mendatang yang online untuk mencari akun orang pertama yang tidak bias (Martin, Woodside \& Dehuang, 2007)

\section{PENUTUP}

\section{Simpulan}

Pemberdayaan masyarakat di RW 13 Kelurahan Panembahan Kraton DIY dilakukan dengan optimalisasi inkubator bisnis dengan berbagai macam kegiatan. Tujuan spesifiknya adalah menambah pendapatan warga masyarakat dan 
meningkatkan kesejahteraannya. Hal ini berjalanan seiring dengan proses pemulihan ekonomi wilayah DIY.

Optimalisasi strategi bisnis dilakukan oleh warga melalui grup whatsapp RW 13 dengan memanfaatkan grup sebagai wahana promosi produk. Warga juga melalukan promosi melalui facebook, instagram. Promosi dengan cara story telling, story marketing juga dapat dilakukan. Market place yang dirancang di RW 13 Panembahan juga bisa dioptimalkan untuk promosi.

\section{Saran}

Disarankan agar pertemuan rutin bulanan warga RW 13 Panembahan tetap dipertahankan untuk menampung aspirasi warga dan perencanaan kegiatan bisnis di masa mendatang. Komunikasi dengan tim pengabdian dari UPN Veteran Yogyakarta tetap dilanjutkan untuk memantau perkembangan bisnis yang sudah dirintis oleh warga masyarakat.

\section{Ucapan Terima Kasih}

Terima kasih kepada LPPM UPN Veteran Yogyakarta yang telah mendukung kegiatan ini

\section{DAFTAR PUSTAKA}

Alhar, Haven dan Candace Brathwaite, 2016, Business Incubation as an instrument of innovation: The ex[eroence of south America and the caribean, International Journal of Innovation (IJI Journal), São Paulo, v. 4, n. 2, pp. 71-85, Juli

Chandra, Aruna; Maria Alejandra Medrano Silva, 2012, Business Incubation in Chile: Development, Financing and Financial Services, J. Technol. Manag. Innov. Volume 7, Issue 2

Khalid, Fararishah Abdul; David Gilbert and Afreen Huq, 2014, The Way Forward for Business Incubation Process in iCT Incubators in Malaysia, nternational Journal of Business and Society, Vol. 15 No. 3 , $395-412$

Li Zhe, 2013, Comparative Study on Start-up Business Incubator Construction Case Study on Incubators in Tianjin, International Conference on Education Technology and Management Science.

Losen, Thobekani Lose and Robertson K. Tengeh, 2015, The Sustainability and Challenges of Business Incubators in the Western Cape Province, South Africa, sustainabilityJournal, 7, 1434414357 
Prochazkova, Petra Tausl, 2015, Said, Mohd Fuaad, Khairul Akmaliah ncubation Activities and Entrepreneurship: Does it Work Together?, Journal of Eastern Europe Research in Business and Economics, Vol. 2015

Pujiastuti, Eny Endah; Humam Santoso, Suratna, 2009, Inkubator Bisnis dalam rangka peningkatan Softskill mahasiswa, Jurnal Paradigma, Volume 13, Nomor 1.

Pujiastuti, Eny Endah; Humam Santoso, Suratna, 2010, Pembelajaran berbasis inkubator Bisnis (Business incubator Based Learning/BIBL), Jurnal Administrasi Bisnis, Volume 7, Nomor 1, Juli 